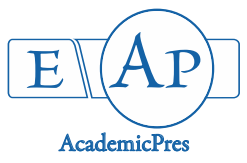

Cornescu F et al. (2020)

Notulae Scientia Biologicae 12(4):836-841

DOI:10.15835/12410752

Research Article

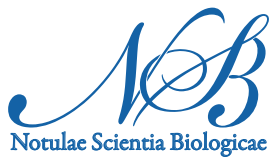

\title{
Vegetative propagation of cornelian cherry (Cornus mas L.) selections
}

\author{
Felicia CORNESCU ${ }^{1}$, Gheorghe ACHIM ${ }^{2,3}$, Sina COSMULESCU ${ }^{2 *}$ \\ ${ }^{1}$ University of Craiova, Faculty of Horticulture, Doctoral School of Plant and Animal Resources Engineering, 13 A.I. Cuza Street, \\ 200585, Craiova, Romania; felicia cornescu@yahoo.com \\ ${ }^{2}$ University of Craiova, Faculty of Horticulture, Department of Horticulture and Food Science, 13 A.I. Cuza Street, 200585 Craiova, \\ Romania; sinacosmulescu@hotmail.com (*corresponding author) \\ ${ }^{3}$ University of Craiova, S.C.D. P. Vâlcea, 464 Calea lui Traian Street, 240273, Râmnicu-Vâlcea, \\ Romania; achimgheorghe555@yahoo.com
}

\begin{abstract}
Cornelian cherry (Cornus mas $\mathrm{L}$ ) is one of the most valuable fruit shrubs of the Cornaceae family, and therefore the vegetative propagation of the valuable selections is necessary because the material obtained must be used for the future. 4 genotypes were studied (2 perspective selections: $\mathrm{H} 1$ and $\mathrm{H} 3$ and two cultivars used as a control: 'De Bucovăț' (B) and 'De Orhei' (O) and propagated by grafting (the grafting method used was improved copulation. Biometric observations were focused on diameter below the point of graft $(\mathrm{mm})$, diameter at the graft point $(\mathrm{mm})$, diameter above the graft point $(\mathrm{mm})$, height of graft $(\mathrm{cm})$, number of anticipated, average length of the anticipated $(\mathrm{cm})$, the sum of the anticipated length $(\mathrm{cm})$, the growth increase $(\mathrm{cm})$. Based on the results obtained, it can be concluded that the grafting method, enhanced copulation, within vegetative propagation, can be successfully used in the production of cornelian cherry planting material next to the other known methods; the growth of the anticipated shoots on plant could cause the appearance of flowering buds and implicitly earliness in fruit-setting.
\end{abstract}

Keywords: Cornus mas L.; genotypes; grafting; propagation

\section{Introduction}

Cornelian cherry (Cornus mas L) Cornaceae family, which grows in many European countries, without commercial plantations (Fedosova and Luigi, 2012). Cornelian cherry is an economically important fruit species due to nutrient rich fruits, which contain a high amount of ascorbic acid. They can be consumed fresh or processed as jelly, compote, juice, jam, syrup or various alcohol-based preparations (Darrow, 1975; Ivanicka and Cvopa, 1977; Pirlak, 2000; Cosmulescu et al., 2019). As in spontaneous flora there are populations obtained through seeds, with cross pollination, the variability is high (Cornescu and Cosmulescu, 2017; Cornescu Fratutu and Cosmulescu 2019; Cosmulescu and Cornescu, 2020) and productivity is variable; thus, the vegetative propagation of valuable selections is indispensable (Pirlak, 2000). Plants obtained from seeds can be different from mother plants in terms of size, shape and quality of fruits. In the last decades the interest for cornelian cherry fruits has increased significantly and the demand for biological material for setting up plantations cannot be satisfied due to the lack of information on propagation methods. Investigating the natural gene pool and breeding new cultivars of Cornelian cherry depends on efficient propagation (Klimenko, 
2004). Biological material obtained generatively can only be fruitful in the year 6-8 after planting, as opposed to the biological material obtained by various methods of vegetative propagation, in which the fruit-setting begins as early as the year 2-3 (Klymenko et al., 2017). The main propagation method is that of grafting with buds on rootstocks obtained from seeds (Fedosova and Luigi, 2012). Also, the clonal propagation of cornelian cherry by cuttings allows the production of propagating material for the selected valuable genotypes (Hassanpour et al., 2014; Marković et al., 2017). Maghradze et al. (2009) reported that budding is the main method of cornelian cherry propagation in Georgia region. In Serbia, the main techniques for the vegetative propagation were budding on seedling rootstocks with $85.9-93.0 \%$ success rate and rooting of green cuttings (Ognjanov et al., 2009).

The present study aimed at the vegetative propagation, by grafting, of valuable and perspective cornelian cherry selections, in order to preserve their genetical characteristics.

\section{Materials and Methods}

The study was carried out at the University of Craiova, Ramnicu-Valcea Fruit and Vegetable Research \& Development Station. Biological material taken into the study was propagated by grafting method with detached branch using improved copulation. The four cornelian cherry genotypes (2 perspective selections: $\mathrm{H} 1$ and $\mathrm{H} 3$ and 2 cultivars of 'De Bucovăț' (B) and 'De Orhei' (O) considered as control, were grafted onto generative rootstocks. At the end of vegetation period of the year 2018 and 2019, the following determinations were made: diameter below grafting point $(\mathrm{mm})$, diameter at the grafting point $(\mathrm{mm})$, diameter above the grafting point $(\mathrm{mm})$, graft height $(\mathrm{cm})$, growth increase $(\mathrm{cm})$, number of anticipated, average length of anticipated $(\mathrm{cm})$, average sum of anticipated length $(\mathrm{cm})$. In order to determine the diameter of biological material, the ultra-fast display calliper with $0.01 \mathrm{~mm}$ precision was used and measurements were made $5 \mathrm{~cm}$ below and above the grafting point, and also at the grafting point (Figure 1). For the height of graft and the length of the anticipated, the measuring tape / meter was used. Data obtained from determinations were processed using the statistical program (StatPoint Technologies, Warrenton, VA, USA).

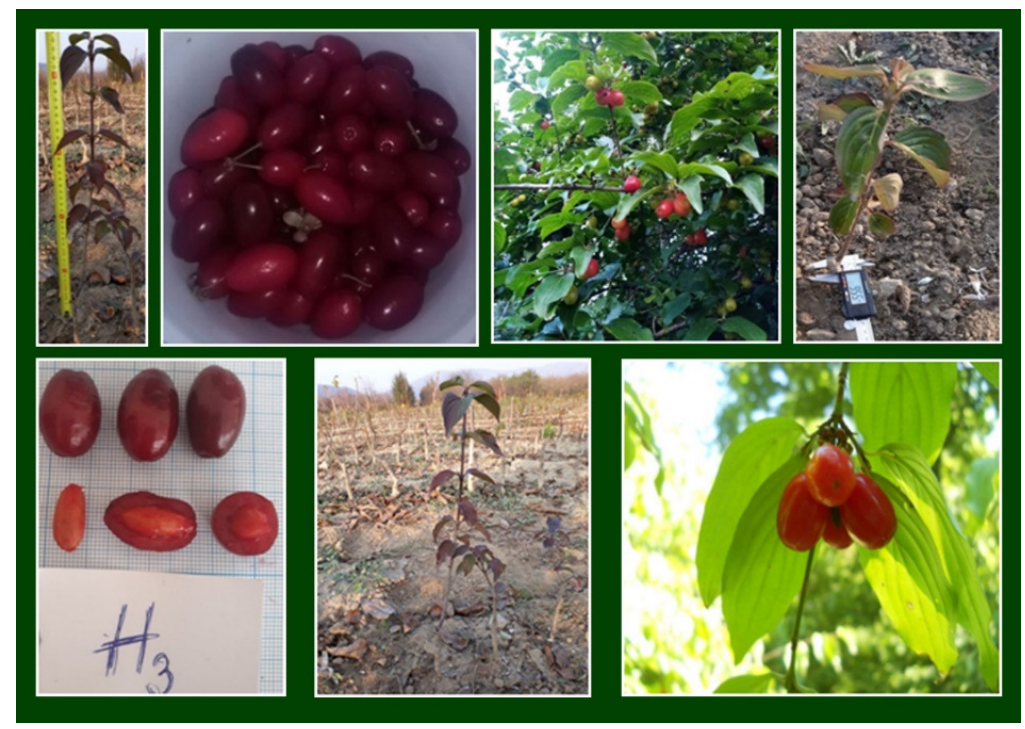

Figure 1. Cornelian cherry (Cornus mas L.) plant and fruits 


\section{Results and Discussion}

The obtained seedling material was monitored in the nursery for two years. As control were used two cultivars 'De Bucovăț' and 'De Orhei', grafted under the same conditions with valuable selections $\mathrm{H} 1$ and $\mathrm{H} 3$. Table 1 shows the results regarding the values obtained for the diameter at the grafting point, below and above the grafting point and the graft / rootstock ratio. There were significant differences between the genotypes studied in terms of characteristics examined. As results from measurements made both in 2018 and 2019, it is observed that the diameter below the grafting point recorded the lowest average value in the control cultivar 'De Bucovăț', respectively $7.93 \mathrm{~mm}$ (2018) and $10.48 \mathrm{~mm}$ (2019), and the highest in 'De Orhei' control cultivar, respectively, $10.93 \mathrm{~mm}$ (2018) and $13.00 \mathrm{~mm}$ (2019). Unlike the two cultivars taken as a control, the selected genotypes $\mathrm{H} 1$ and $\mathrm{H} 3$ presented intermediate values, $7.94 \mathrm{~mm}(\mathrm{H} 3)$ and $8.49 \mathrm{~mm}(\mathrm{H} 1)$ in 2018 , respectively, $12.21 \mathrm{~mm}(\mathrm{H} 3)$ and $11.46 \mathrm{~mm}(\mathrm{H} 1)$ in 2019. An average variability for this characteristic was observed in H1, 'De Bucovăț' and 'De Orhei' genotypes (CV\% = 12.27-13.77), and high variability in H3 $(\mathrm{CV} \%=21.12)$. Regarding the diameter at the grafting point, the average values in 2018 varied between 8.59 $\mathrm{mm}$ in 'De Bucovăț' and $12.88 \mathrm{~mm}$ in 'De Orhei'. $\mathrm{H} 1$ and $\mathrm{H} 3$ selections recorded average values between 8.81 $\mathrm{mm}(\mathrm{H} 3)$ and $9.35 \mathrm{~mm}(\mathrm{H} 1)$. In 2019, the average diameter at the grafting point recorded the lowest average values in $\mathrm{H} 1$ genotype $(14.39 \mathrm{~mm})$ and 'De Bucovăț' control cultivar $(13.46 \mathrm{~mm})$, and the highest average value in 'De Orhei' control cultivar $(17.50 \mathrm{~mm})$. The diameter above the grafting point recorded the lowest value in 2018 in $\mathrm{H} 1$ genotype $(6.33 \mathrm{~mm})$ and the highest in 'De Orhei' cultivar $(8.57 \mathrm{~mm})$, and in 2019 it had values between $9.11 \mathrm{~mm}$ ('De Bucovăț') and $11.36 \mathrm{~mm}$ (H3). The authors observe the relatively high variability in the biological material under study. The results obtained are in accordance with those of the literature. Bijelic et al. (2016) reported a diameter of plants obtained by grafting in the spring season, with values between 10.00 $\mathrm{mm}$ and $13.61 \mathrm{~mm}$. The ratio between the graft diameter and rootstock diameter (measured at $5 \mathrm{~cm}$ from the graft point) recorded subunit values between 0.86 and 0.93 (in the second year of observation), which indicates a good compatibility between the two partners.

Table 1. Average growth diameter in biologic material of Cornelian cherry in training fields of nursery (2018-2019)

\begin{tabular}{|c|c|c|c|c|c|c|c|c|}
\hline \multirow[t]{2}{*}{ Specification } & \multirow[t]{2}{*}{ Statistic } & \multicolumn{2}{|c|}{$\begin{array}{l}\text { Average diameter } \\
\text { under grafting point } \\
(\mathrm{mm})\end{array}$} & \multicolumn{2}{|c|}{$\begin{array}{l}\text { Average diameter at } \\
\text { the grafting point } \\
(\mathrm{mm})\end{array}$} & \multicolumn{2}{|c|}{$\begin{array}{c}\text { Average diameter } \\
\text { above the grafting } \\
\text { point }(\mathrm{mm})\end{array}$} & \multirow{2}{*}{$\begin{array}{c}\text { Graft/ } \\
\text { rootstock } \\
\text { ratio } \\
2019\end{array}$} \\
\hline & & 2018 & 2019 & 2018 & 2019 & 2018 & 2019 & \\
\hline \multirow[t]{2}{*}{$\mathrm{H} 1$} & Mean \pm SD & $\begin{array}{r}8.49 \\
\pm 1.04\end{array}$ & $\begin{array}{r}11.46 \\
\pm 1.89\end{array}$ & $\begin{array}{r}9.35 \\
\pm 1.41\end{array}$ & $\begin{array}{r}14.39 \\
\pm 2.16\end{array}$ & $\begin{array}{c}6.33 \\
\pm 0.87\end{array}$ & $\begin{array}{r}9.88 \\
\pm 1.72\end{array}$ & 0.86 \\
\hline & $\mathrm{Cv} \%$ & 12.27 & 16.46 & 15.03 & 15.03 & 13.73 & 17.45 & \\
\hline \multirow[t]{2}{*}{$\mathrm{H} 3$} & Mean \pm SD & $\begin{array}{c}7.94 \\
\pm 1.68\end{array}$ & $\begin{array}{c}12.21 \pm \\
2.49\end{array}$ & $\begin{array}{c}8.81 \\
\pm 2.14\end{array}$ & $\begin{array}{l}15.37 \\
\pm 3.07\end{array}$ & $\begin{array}{c}7.31 \\
\pm 1.86\end{array}$ & $\begin{array}{l}11.36 \\
\pm 2.41\end{array}$ & 0.93 \\
\hline & $\mathrm{Cv} \%$ & 21.12 & 20.41 & 24.3 & 19.97 & 25.39 & 21.23 & \\
\hline \multirow[t]{2}{*}{ De Bucovăț } & Mean \pm SD & $\begin{array}{c}7.93 \\
\pm 1.09\end{array}$ & $\begin{array}{l}10.48 \\
\pm 2.09\end{array}$ & $\begin{array}{c}8.59 \\
\pm 1.31\end{array}$ & $\begin{array}{l}13.46 \\
\pm 3.03\end{array}$ & $\begin{array}{c}6.49 \\
\pm 1.13\end{array}$ & $\begin{array}{c}9.11 \\
\pm 2.17\end{array}$ & 0.87 \\
\hline & $\mathrm{Cv} \%$ & 13.77 & 20.00 & 15.27 & 22.52 & 17.46 & 23.87 & \\
\hline \multirow[t]{2}{*}{ De Orhei } & Mean $\pm S D$ & $\begin{array}{l}10.93 \\
\pm 1.36\end{array}$ & $\begin{array}{l}13.00 \\
\pm 1.55\end{array}$ & $\begin{array}{r}12.88 \\
\pm 3.28\end{array}$ & $\begin{array}{l}17.50 \\
\pm 7.62\end{array}$ & $\begin{array}{c}8.57 \\
\pm 1.64\end{array}$ & $\begin{array}{l}11.17 \\
\pm 3.47\end{array}$ & 0.86 \\
\hline & $\mathrm{Cv} \%$ & 12.44 & 11.91 & 25.44 & 43.56 & 19.14 & 31.10 & \\
\hline
\end{tabular}

$\mathrm{SD}=$ Standard deviation; $\mathrm{CV} \%=$ coefficient of variation 
The area of the trunk section area (SST) was also calculated in order to observe in section the increase in the symbionts' thickness (Table 2). The highest calculated value of the trunk section area, at the grafting point, was observed in 'De Orhei' cultivar, $135.92 \mathrm{~mm}^{2}$ in 2018, respectively, $270.00 \mathrm{~mm}^{2}$ in 2019 . The values recorded in $\mathrm{H} 1$ and $\mathrm{H} 3$ selections $\left(165.89 \mathrm{~mm}^{2}\right.$, respectively, $191.69 \mathrm{~mm}^{2}$ ), were higher than 'De Bucovăț' cultivar $\left(148.30 \mathrm{~mm}^{2}\right)$ and lower than 'De Orhei' cultivar $\left(270.00 \mathrm{~mm}^{2}\right)$, taken as a control. Regarding the other morphological determinations of quality of the examined seedling material, in Table 3 are presented the values of growth elements such as the graft height over the two years, the growth increase, the number of anticipated in the 2nd year after grafting, the length and the sum of their average length. Thus, the graft presented a height between $18.76 \mathrm{~cm}(\mathrm{H} 1)$ and $23.50 \mathrm{~cm}(\mathrm{H} 3)$ with limits of variation between $5 \mathrm{~cm}(\mathrm{H} 1)$ and $50 \mathrm{~cm}$ in 'De Orhei' in 2018, and in 2019 the average value of the height varied between $62 \mathrm{~cm}$ in 'De Orhei' and $103 \mathrm{~cm}(\mathrm{H} 3)$, with limits of variation between $32 \mathrm{~cm}$ in 'De Orhei' and $116 \mathrm{~cm}(\mathrm{H} 3)$. The variability for graft height was very high, in all genotypes analysed. The values obtained are in accordance with those obtained by Bijelic et al. (2016), respectively, $74.02 \mathrm{~cm}$ and $91.18 \mathrm{~cm}$. Based on the values recorded for the height increase of the graft over the two years, the growth gain was calculated, which achieved the highest average value in $\mathrm{H} 3$ selection $(80.17 \mathrm{~cm})$, and the lowest in 'De Orhei' cultivar $(39.67 \mathrm{~cm})$, with limits of variation between $18 \mathrm{~cm}$ 'De Bucovăț' and $100 \mathrm{~cm}(\mathrm{H} 1)$. It is thus observed that the $\mathrm{H} 1$ and $\mathrm{H} 3$ selected genotypes taken under study showed a higher growth rate than 'De Bucovăț' and 'De Orhei' cultivars, taken as a control. Regarding the number of anticipated shoots/trees in the 2 nd field of the nursery (2019), it showed variation limits between 1 (H1) and 12 (H3), unlike Bijelic et al. (2016) which reported between 4 and 5 anticipated. The average length of the anticipated ones was relatively higher in the two selections $(\mathrm{H} 1$ and $\mathrm{H} 3)$ compared to control cultivars ('De Orhei' and 'De Bucovăț'), and the variation limits were between $8 \mathrm{~cm}(\mathrm{H} 1)$ and $29 \mathrm{~cm}(\mathrm{H} 3$ and 'De Orhei'). The average sum of anticipated shoots per plant has recorded higher values in $\mathrm{H} 1$ and $\mathrm{H} 3$ selections, compared to 'De Orhei' and 'De Bucovăț' cultivars taken as control.

Table 2. Area of trunk section (SST) in cornelian cherry biologic material in training fields of nursery (2018 and 2019)

\begin{tabular}{|c|c|c|c|c|c|c|c|}
\hline \multirow[t]{2}{*}{ Specification } & \multirow[t]{2}{*}{ Analysis } & \multicolumn{2}{|c|}{ SST under graft point $\left(\mathrm{mm}^{2}\right)$} & \multicolumn{2}{|c|}{ SST at the graft point $\left(\mathrm{mm}^{2}\right)$} & \multicolumn{2}{|c|}{$\begin{array}{l}\text { SST above graft } \\
\text { point }\left(\mathrm{mm}^{2}\right)\end{array}$} \\
\hline & & 2018 & 2019 & 2018 & 2019 & 2018 & 2019 \\
\hline \multirow[t]{2}{*}{$\mathrm{H} 1$} & Mean \pm SD & $57.40 \pm 13.76$ & $105.71 \pm 34.83$ & $70.10 \pm 21.67$ & $165.89 \pm 49.53$ & $\begin{array}{r}32.00 \\
\pm 8.55 \\
\end{array}$ & $\begin{array}{c}78.82 \\
\pm 27.56 \\
\end{array}$ \\
\hline & $\mathrm{CV} \%$ & 23.96 & 32.95 & 30.91 & 29.85 & 26.71 & 34.96 \\
\hline \multirow[t]{2}{*}{$\mathrm{H} 3$} & Mean \pm SD & $51.3 \pm 20.22$ & $121.11 \pm 49.15$ & $63.88 \pm 30.29$ & $191.69 \pm 74.52$ & $\begin{array}{r}44.20 \\
\pm 21.12\end{array}$ & $\begin{array}{r}105.05 \\
\pm 42.69\end{array}$ \\
\hline & $\mathrm{CV} \%$ & 39.41 & 40.58 & 47.41 & 38.87 & 47.78 & 40.64 \\
\hline \multirow[t]{2}{*}{ 'De Bucovăț' } & Mean \pm SD & $50.20 \pm 13.19$ & $89.01 \pm 34.48$ & $59.09 \pm 18.30$ & $148.30 \pm 72.35$ & $\begin{array}{c}33.87 \\
\pm 11.50 \\
\end{array}$ & $\begin{array}{c}68.18 \\
\pm 32.70 \\
\end{array}$ \\
\hline & $\mathrm{CV} \%$ & 26.08 & 38.74 & 30.97 & 48.78 & 33.96 & 47.96 \\
\hline \multirow[t]{2}{*}{ 'De Orhei' } & Mean \pm SD & $94.66 \pm 24.13$ & $133.85 \pm 32.56$ & $135.92 \pm 62.76$ & $270 \pm 235.41$ & $\begin{array}{r}59.02 \\
\pm 20.84 \\
\end{array}$ & $\begin{array}{r}104.26 \\
\pm 65.60 \\
\end{array}$ \\
\hline & $\mathrm{CV} \%$ & 25.48 & 24.32 & 46.17 & 86.97 & 35.91 & 62.91 \\
\hline
\end{tabular}


Table 3. Morphological properties of one-year nursery plants four selection of cornelian cherry

\begin{tabular}{|c|c|c|c|c|c|c|c|}
\hline \multirow{2}{*}{ Specification } & \multirow{2}{*}{ Statistic } & \multicolumn{2}{|c|}{ Graft height $(\mathrm{cm})$} & \multirow{2}{*}{$\begin{array}{c}\text { Growth } \\
\text { increase }(\mathrm{cm})\end{array}$} & \multirow{2}{*}{$\begin{array}{c}\begin{array}{c}\text { Number of } \\
\text { anticipated }\end{array} \\
2019\end{array}$} & \multirow{2}{*}{$\begin{array}{l}\text { Average } \\
\text { length of } \\
\text { anticipated } \\
(\mathrm{cm}) \\
2019\end{array}$} & \multirow{2}{*}{$\begin{array}{c}\begin{array}{c}\text { Average } \\
\text { sum of }\end{array} \\
\text { anticipated } \\
\text { (cm) } \\
2019\end{array}$} \\
\hline & & 2018 & 2019 & & & & \\
\hline \multirow[t]{2}{*}{$\mathrm{H} 1$} & $\begin{array}{c}\text { Meant } \\
\text { SD }\end{array}$ & $18.76 \pm 10.98$ & $79.71 \pm 19.56$ & $60.95 \pm 20.86$ & $4.47 \pm 2.48$ & $\begin{array}{r}18.42 \\
\pm 7.15\end{array}$ & 82.34 \\
\hline & CV\% & 58.52 & 23.54 & 34.62 & 55.43 & 38.79 & - \\
\hline \multirow[t]{2}{*}{$\mathrm{H} 3$} & $\begin{array}{c}\text { Mean } \pm \\
\text { SD }\end{array}$ & $23.50 \pm 11.83$ & $103.67 \pm 8.69$ & $80.17 \pm 9.02$ & $5.67 \pm 3.67$ & $\begin{array}{r}13.62 \\
\pm 3.80\end{array}$ & 77.23 \\
\hline & $\mathrm{CV} \%$ & 55.33 & 8.38 & 11.25 & 64.76 & 27.90 & - \\
\hline \multirow[t]{2}{*}{ 'De Bucovăț' } & $\begin{array}{c}\text { Mean } \pm \\
\text { SD }\end{array}$ & $20.33 \pm 13.38$ & $72.00 \pm 31.46$ & $51.67 \pm 23.82$ & $4.50 \pm 2.17$ & $\begin{array}{r}11.49 \\
\pm 5.57\end{array}$ & 51.71 \\
\hline & CV\% & 65.81 & 43.70 & 46.1 & 48.18 & 48.44 & - \\
\hline \multirow[t]{2}{*}{ 'De Orhei' } & $\begin{array}{c}\text { Mean } \pm \\
\text { SD }\end{array}$ & $22.33 \pm 24.01$ & $62.00 \pm 42.79$ & $39.67 \pm 19.76$ & $3.33 \pm 1.15$ & $\begin{array}{r}18.33 \\
\pm 10.07 \\
\end{array}$ & 61.00 \\
\hline & $\mathrm{CV} \%$ & 107.49 & 69.02 & 49.8 & 34.64 & 54.91 & - \\
\hline
\end{tabular}

\section{Conclusions}

The difference in growth between the 2 symbionts $(5 \mathrm{~cm}$ below and above the grafting point) is insignificant and thus the values of graft and rootstock ratio are low, indicating a good compatibility between the partners. The increase in graft height over $79.00 \mathrm{~cm}$ in $\mathrm{H} 1$, respectively, $103.00 \mathrm{~cm}$ in $\mathrm{H} 3$, and the production of the anticipated in the 2nd field of nursery indicate a good development especially in the two studied selections. The growth of the anticipated shoots on plant could cause the appearance of flowering buds and implicitly earliness in fruit-setting. Based on the results obtained, it can be concluded that the grafting method, enhanced copulation, within vegetative propagation, can be successfully used in the production of cornelian cherry planting material next to the other known methods.

\section{Authors' Contributions}

Conceptualization: SC, FC and GA; Data curation: SC and GA; Methodology: GA; Writing: FC; Writing - review and editing: SC. All authors read and approved the final manuscript.

\section{Acknowledgements}

This research received no specific grant from any funding agency in the public, commercial, or not-forprofit sectors.

\section{Conflict of Interests}

The authors declare that there are no conflicts of interest related to this article. 


\section{References}

Bijelic SM, Gološin BR, Cerović SB, Bogdanović BV (2016). A comparison of grafting methods for the production of quality planting material of promising cornelian cherry selections (Cornus mas L.) in Serbia. Journal of Agricultural Science and Technology 18(1):223-231.

Cornescu FC, Cosmulescu SN (2017). Morphological and biochemical characteristics of fruits of different cornelian cherry (Cornus mas L.) genotypes from spontaneous flora. Notulae Scientia Biologicae 9(4):577-581. https://doi.org/10.15835/nsb9410161

Cornescu Fratutu F, Cosmulescu S (2019). Variability of morphological characteristics in genotypes of Cornus mas L. identified in Oltenia region. Scientific Papers. Series B. Horticulture 63(1):85-91

Cosmulescu SN, Trandafir I, Cornescu F (2019). Antioxidant capacity, total phenols, total flavonoids and colour component of cornelian cherry (Cornus mas L.) wild genotypes. Notulae Botanicae Horti Agrobotanici ClujNapoca 47(2):390-394. https://doi.org/10.15835/nbha47111375

Cosmulescu S, Cornescu F (2020). Variability in physical and chemical characteristics of Cornelian cherry fruits (Cornus mas L.) from Romanian Oltenia region's spontaneous flora and role of the climatic conditions. Brazilian Journal of Botany. https://doi.org/10.1007/s40415-020-00615-6

Darrow GM (1975). Minor fruits. advanced in fruit breeding. Janick J, Moore JN (Eds). Purdue Univ. Press. West Lafayette, Indiana, pp 623.

Fedosova K, Luigi FD (2012). Cornelian cherry (dogwood) in south of Ukraine. Харчова наука і технологія (2):60-64.

Hassanpour H, Shiri MA (2014). Propagation of Iranian Cornelian cherry (Cornus mas L.) by rooted stem cuttings. Notulae Scientia Biologicae 6(2):192-195. https://doi.org/10.15835/nsb629295

Ivanicka J, Cvopa J (1977). Propagation of dogwood (Cornus mas L.) by softwood and semi-hardwood cuttings. Gartenbauwissenchaft 42(4):169-171. https://doi.org/10.15835/nsb629295

Klimenko S (2004). The cornelian cherry (Cornus mas L.): collection, preservation, and utilization of genetic resources. Journal of Fruit and Ornamental Plant Research 12:93-98.

Klymenko S, Grygorieva O, Onyshuk L (2017). Biological bases of seed and vegetative reproduction of cornelian cherry (Cornus mas L.) in nature and culture. Agrobiodiversity for Improving Nutrition, Health and Life Quality 1:233-248. http://dx.doi.org/10.15414/agrobiodiversity.2017.2585-8246.233-248.

Maghradze D, Abashidze E,Bobokashvili Z, Tchipashvili R, Maghlakelidze E (2009). Cornelian Cherry in Georgia. Acta Horticulturae 818:65-72. https://doi.org/10.17660/ActaHortic.2009.818.8

Marković M, Skočajić D, Grbić M, Đukić M (2017). Vegetative propagation of elite trees of Cornus mas L. in the Belgrade area by softwood cuttings. In VIII International Scientific Agriculture Symposium pp 2646-2652.

Ognjanov V, Cerović S, Ninić-Todorović J, Jaćimović V, Gološin B, Bijelić S, Vračević B (2009). Selection and utilization of table cornelian cherry (Cornus mas L.). Acta Horticulturae 814:121-124. https://doi.org/10.17660/ActaHortic.2009.814.13

Pirlak L (2000). Effects of different cutting times and IBA doses on the rooting rate of hardwood cuttings of cornelian cherry (Cornus mas L.). Anadolu 10(1):122-134.
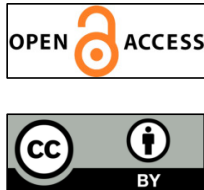

The journal offers free, immediate, and unrestricted access to peer-reviewed research and scholarly work. Users are allowed to read, download, copy, distribute, print, search, or link to the full texts of the articles, or use them for any other lawful purpose, without asking prior permission from the publisher or the author.

License - Articles published in Notulae Scientia Biologicae are Open-Access, distributed under the terms and conditions of the Creative Commons Attribution (CC BY 4.0) License.

(c) Articles by the authors; SHST, Cluj-Napoca, Romania. The journal allows the author(s) to hold the copyright/to retain publishing rights without restriction. 